\title{
Program Keluarga Harapan dalam Mendukung Taraf Hidup Masyarakat: Kajian Implementasi di Parepare
}

\author{
${ }^{1}$ Sulkarnain, ${ }^{2}$ Arwin, ${ }^{3}$ Fitriawaty \\ ${ }^{1,2}$ IAIN Parepare \\ ${ }^{3}$ BPTP Balitbangtan Sulawesi Barat \\ Email Korespondensi: sulkarnain@iainpare.ac.id
}

\begin{abstract}
Abstrak. Program keluarga harapan (PKH) adalah program pemerintah yang merupakan bantuan sosial bersyarat bagi keluarga penerima manfaat (KPM). Program tersebut bertujuan untuk meningkatkan kualitas sumber daya manusia masyarakat baik pendidikan maupun kesehatan. Penelitian ini bertujuan untuk mengetahui implementasi PKH di Kota Parepare. Penelitian dilaksanakan di UPPKH Kota Parepare. Penelitian ini adalah kualitatif dengan mengkaji data-data dari laporan Badan Pusat Statistik yang relevan dengan penelitian ini. Hasil penelitian menunjukkan bahwa implementasi PKH di Kota Parepare meningkat dalam rata-ratanya. Pelaksanaan PKH dimulai tahun 2013 hingga saat ini dengan jumlah KPM tahun 2020 yaitu 3.168 keluarga. Dalam pelaksanaanya PKH didukung oleh SDM profesional di bidangnya, dukungan fasilitas pendidikan dan kesehatan yang memadai serta pelaksanaan Pertemuan Peningkatan Kapasitas Keluarga (P2K2) yang telah terlaksana secara rutin setiap bulan yang memiliki pendamping pada masingmasing wilayah dampingan di Parepare. PKH ini sedang menjadi peningkatan taraf hidup masyarakat khususnya menyediakan kesempatan untuk mengakses pendidikan dan kesehatan kepada KPM PKH.
\end{abstract}

Kata kunci: Implementasi, Kemiskinan, PKH

\section{PENDAHULUAN}

Pembukaan Undang-Undang Dasar 1945 mengamanatkan kepada rakyat bahwa upaya penanggulangan kemiskinan merupakan perlindungan segenap bangsa Indonesia dan seluruh tumpah darah Indonesia, memajukan kesejahteraan umum, mencerdaskan kehidupan bangsa dan ikut melaksanakan ketertiban dunia yang berdasarkan kemerdekaan, perdamaian abadi dan keadilan sosial (Purwanto, et al., 2013).

Permasalahan utama dalam kehidupan bernegara yang sifatnya sangat penting untuk dipecahkan adalah kemiskinan. Penanggulangan kemiskinan terus dilakukan melalui sinergi tersistematis agar semua warga negara mampu menikmati kehidupan bermartabat (Kementerian Komunikasi dan Informatika, 2011). Pada Maret 2020, dilaporkan bahwa persentase penduduk miskin di Indonesia 9,78\% atau sebanyak 26,42 juta orang (BPS, 2020a). Sedangkan di Kota Parepare disebutkan bahwa persentase penduduk miskin sebanyak $5,26 \%$ atau sebanyak 7620 orang (BPS, 2020a).

Saat ini, konsep kemiskinan bukan hanya meliputi masalah ekonomi keuangan akan tetapi mencakup aspek sosial.
Kemiskinan bukanlah ketidakmampuan seseorang dalam hal memenuhi kebutuhan dasarnya, tetapi mencakup kemampuan dalam mengakses pelayanan hidup dasar yang memadai. Sugandi (2016) menjelaskan bahwa kondisi kemiskinan memberi pengaruh masalah sosial yang dihadapi oleh masyarakat di Indonesia, misalnya adanya kekurangan makanan, kesehatan, pendidikan, pengangguran, gizi buruk dan lain-lain.

Suatu penanggulangan kemiskinan merupakan permasalahan kompleks dan multidimensi sehingga untuk mengatasi hal tersebut dibutuhkan suatu upaya kolektif dari pihak pemerintah maupun masyarakat sekitar yang berupa strategi yang bersifat komprehensif, terpadu, terarah, dan berkelanjutan.

Pengentasan kemiskinan terus dilakukan oleh pemerintah melalui programprogram pengentasan kemiskinan. berbagai macam program telah dilaksanakan untuk meningkatkan taraf hidup masyarakat. Salah satu program pemerintah dalam penanggulangan kemiskinan adalah Program Keluarga Harapan (PKH). PKH merupakan program pemberian bantuan sosial (BANSOS) bersyarat bagi masyarakat miskin 
dan rentan yang terdaftar dalam Data Terpadu Kesejahteraan Sosial (DTKS) dan ditetapkan sebagai keluarga penerima manfaat (KPM) PKH. Program ini telah diluncurkan sejak tahun 2007, yang dikenal sebagai Conditional Cash Transfers (CCT). Program ini telah memberi kontribusi dalam menekan angka kemiskinan dan mendorong kemandirian kepada KPM (Kemensos, 2020).

Parepare merupakan salah satu Kota yang melaksanakan Program Keluarga Harapan (PKH) yang dimulai sejak 20132020. Penelitian ini bertujuan untuk melihat pelaksanaan PKH di Kota Parepare selama tahun 2019 di saat pandemi corona 2020. Pandemi tersebut sudah menyebabkan keprihatinan dalam perekonomian nasional (Abbas, et al., 2020; Arizah, et al., 2020). Oleh karena itu, keluarga penerima Program Keluarga Harapan cenderung dianggap meningkat selama tahun 2019 dan 2020.

\section{METODE PENELITIAN}

Penelitian ini adalah kualitatif yang dilaksanakan di UPPKH Kota Parepare. Metode penelitian ini menggunakan studi kepustakaan yang memanfaatkan data-data sekunder yang berasal dari dokumen laporan statistik dan profil demografi masyarakat Parepare. Teknik analisis data menggunakan deskripsi statistik. Data bersifat time-series dengan periode laporan lima tahun terakhir dan periode 2019 dan 2020 menjadi periode analisis utama dalam menginterpretasikan data.

\section{HASIL DAN PEMBAHASAN \\ Gambaran Umum Kota Parepare}

Kota Parepare merupakan salah satu Kabupaten/Kota yang terletak di Provinsi Sulawesi Selatan. Secara astronomis, Kota Parepare terletak antara 3057'39' dan 4004'59" Lintang Selatan dan antara 119036'24" dan 119043'40" Bujur Timur. Berdasarkan posisi geografisnya, Kota Parepare berbatasan dengan Kabupaten Pinrang disebelah Utara, Kabupaten Barru di sebelah Selatan, Kabupaten Sidenreng Rappang disebelah Timur dan disebelah barat berbatasan dengan Selat Makassar. Kota Prepare terdiri atas 4 kecamatan yaitu
Kecamatan Bacukiki, Kecamatan Bacukiki Barat, Kecamatan Ujung dan Kecamatan Soreang. Pada Tahun 2019 dilaporkan jumlah penduduk kota Parepare sebanyak 148260 jiwa (BPS, 2020a).

Perekonomian Kota Parepare didominasi oleh sektor pertanian yang diikuti oleh industri pengolahan, listrik gas dan air bersih, angkutan dan komunikasi serta bank dan lembaga keuangan. Pada umumnya lapangan kerja masyarakat Parepare bergerak dibidang pertanian $3,21 \%$, Industri $37,18 \%$, Perdagangan $25,11 \%$ Jasa $18,41 \%$ dan Lainnya 16,09\% (Pemerintah Kota Parepare, 2019). Berikut Jumlah penduduk miskin kota Parepare dari selama 5 tahun terakhir (20152019).

Tabel 1. Jumlah dan Persentase Penduduk Miskin Kota Parepare (2015-2019)

\begin{tabular}{ccc}
\hline Tahun & $\begin{array}{c}\text { Jumlah } \\
\text { Penduduk } \\
\text { Miskin }\end{array}$ & Persentase \\
\hline $2015^{*}$ & 8410 & 6,08 \\
$2016^{*}$ & 8020 & 5,73 \\
$2017^{*}$ & 8070 & 5,70 \\
$2018^{* *}$ & 8010 & 5,59 \\
$2019^{* *}$ & 7620 & 5,26 \\
\hline Sumber: * BPS (2018) **BPS (2020a).
\end{tabular}

\section{Pelaksanaan Program Keluarga Harapan di Kota Parepare}

Pelaksanaan PKH di Kota Parepare telah dilaksanakan sejak tahun 2013 hingga saat ini. Pemerintah Kota Parepare sangat mendukung pelaksanaan program ini. PKH merupakan program bantuan pemerintah yang sifatnya bersyarat dengan fokus pada pengembangan perlindungan sosial yang sifatnya meringankan beban keluarga sangat miskin sehingga memudahkan untuk mendapatkan akses pelayanan pendidikan maupun pelayanan fasilitas kesehatan. Dalam pelaksaannya PKH melibatkan beberapa kementerian diantaranya Kementerian Sosial, Kementerian Pendidikan dan Kebudayaan, Kementerian Agama, Kementerian Kesehatan, Kementerian Komunikasi dan Informatika serta Badan Statistik Nasional, pelaksanaannya pun melibatkan tim tenaga 
ahli dalam program ini serta konsultan (Kemensos, 2008).

Keluarga yang menjadi sasaran PKH merupakan keluarga miskin dan rentan miskin yang terdaftar dalam Data Terpadu Kesejahteraan Sosial (DTKS). Berikut kriteria keluarga penerima (KPM) PKH (Kemensos, 2020).

a) Komponen kesehatan dimana keluarga tersebut memiliki ibu hamil atau balita dengan usia 0-6 tahun

b) Komponen pendidikan, dimana keluarga tersebut memiliki anak usia sekolah SD, SMP, dan SMA atau sederajat.

c) Komponen kesejahteraan sosial, pada penyandang disabilitas berat dan lanjut usia.

Tabel 2. Jumlah KPM PKH Kota Parepare Tahun 2013-2020

\begin{tabular}{lcccc}
\hline \multirow{1}{*}{ Kec } & \multicolumn{4}{c}{ Tahun Pelaksanaan } \\
\cline { 2 - 5 } & $\mathbf{2 0 1 3}$ & $\mathbf{2 0 1 4}$ & $\mathbf{2 0 1 5}$ & $\mathbf{2 0 1 6}$ \\
\hline Bacukiki & 192 & 182 & 179 & 176 \\
Bacukiki Barat & 242 & 233 & 229 & 226 \\
Soreang & 187 & 181 & 178 & 170 \\
Ujung & - & - & 202 & 197 \\
\hline Jumlah & $\mathbf{6 2 1}$ & $\mathbf{5 9 6}$ & $\mathbf{7 8 8}$ & $\mathbf{7 6 9}$ \\
\hline \multicolumn{1}{c}{ Kec } & \multicolumn{5}{c}{ Tahun Pelaksanaan } \\
\cline { 2 - 5 } & $\mathbf{2 0 1 7}$ & $\mathbf{2 0 1 8}$ & $\mathbf{2 0 1 9}$ & $\mathbf{2 0 2 0}$ \\
\hline Bacukiki & 515 & 594 & 575 & 584 \\
Bacukiki Barat & 647 & 1090 & 1030 & 1045 \\
Soreang & 571 & 1001 & 984 & 1014 \\
Ujung & 266 & 463 & 456 & 525 \\
\hline Jumlah & $\mathbf{1 9 9 9}$ & $\mathbf{3 1 4 8}$ & $\mathbf{3 0 4 5}$ & $\mathbf{3 1 6 8}$ \\
\hline
\end{tabular}

Sumber: UPPKH Kota Parepare

Berdasarkan data tersebut diatas menunjukkan bahwa pelaksanaan PKH di Kota Parepare dimulai pada tahun 2013 dan 2014, dan baru dilaksanakan pada 3 Kecamatan yaitu Kecamatan Bacukiki, Bacukiki Barat, dan Soreang. Tahun 20152016 semua kecamatan di Kota Parepare menjadi pelaksana PKH. Terlihat bahwa setiap tahun jumlah keluarga penerima manfaat PKH menunjukkan peningkatan jumlah KPM hal tersebut disebabkan karena adanya peningkatan target sasaran keluarga penerima manfaat dan alokasi anggaran yang meningkat setiap tahunnya. Diharapkan dengan adanya pemberian bantuan tunai bersyarat dari pemerintah melalui program ini dapat mendorong perubahan perilaku penerima manfaat $\mathrm{PKH}$, mempermudah akses fasilitas pendidikan dan kesehatan (Ditjen Anggaran, 2015).

KPM PKH di Kota Parepare memiliki hak dan kewajiban sebagai KPM PKH sesuai dengan Kemensos 2020 yaitu memiliki hak diantaranya mendapatkan bantuan sosial, pendampingan sosial, mendapatkan pelayanan pada fasilitas kesehatan dan fasilitas pendidikan, dan kesejahteraan sosial serta menerima bantuan yang sifatnya komplementer. Adapun kewajiban bagi KPM PKH yaitu anggota keluarga dengan kategori ibu hamil dan balita wajib melakukan pemeriksaan kesehatan rutin di fasilitas kesehatan. Anggota keluarga dengan kategori pendidikan wajib mengikuti kegiatan belajar mengajar di sekolah dengan persentase kehadiran $85 \%$ dari hari belajar efektif, KPM wajib mengikuti kegiatan pertemuan kelompok atau pertemuan peningkatan kapasitas keluarga (P2K2).

\section{Sumber Daya Pelaksanaan Program Keluarga Harapan di Kota Parepare}

Implementasi PKH di Kota Parepare terlaksana dengan adanya dukungan sumber daya pada pelaksanaannya. Pelaksanaan PKH kota Parepare didukung oleh sumber daya manusia yang kompeten. Berikut data sumber daya manusia yang mendukung pelaksanaannya.

Tabel 3. Sumber Daya Manusia Pelaksana PKH Kota Parepare

\begin{tabular}{lcc}
\hline \multicolumn{1}{c}{$\begin{array}{c}\text { Kategori SDM } \\
\text { PKH }\end{array}$} & Jum & $\begin{array}{c}\text { Jenjang } \\
\text { pendidikan }\end{array}$ \\
\hline Koordinator Kota & 1 & $\mathrm{~S} 1$ \\
Administrator & 2 & $\mathrm{~S} 1$ \\
Supervisor & 1 & $\mathrm{~S} 1$ \\
Pendamping & 10 & $\mathrm{~S} 1$ \\
Kecamatan & & \\
\hline
\end{tabular}

Sumber: UPPKH Kota Parepare, 2020.

Sumber daya manusia yang mendukung pelaksanaan $\mathrm{PKH}$ ini tentu memiliki peran penting untuk mencapai tujuan dari PKH ini yaitu masyarakat yang maju mandiri dan sejahtera. Berdasarkan jenjang pendidikan yang mana semua SDM PKH dengan memiliki jenjang pendidikan S1/sederajat 
menunjukkan bahwa semua SDM PKH Kota Parepare berdasarkan kualifikasi pendidikan merupakan SDM yang bermutu. Setiap SDM PKH dibekali dengan pendidikan yang berkaitan dengan pelaksanaan PKH di lapangan diantaranya pendidikan dan pelatihan (diklat), bimbingan teknis, dan pelatihan pelaksanaan P2K2. Kegiatan tersebut merupakan persiapan sumber daya pendamping di lapangan dalam pelaksanaan PKH. mengingat peran SDM sangat penting dalam kesuksesan pelaksanaan PKH di lapangan, sehingga SDM dikelola secara profesional dan peningkatan kompetensi SDM, kepribadian, ketertiban akan administrasi (Aliman, 2019).

\section{Dukungan Fasilitas Pendidikan}

KPM PKH berhak menerima layanan pendidikan bagi keluarga yang memiliki komponen dengan kategori pendidikan dan selanjutnya memiliki kewajiban mengikuti kegiatan belajar mengajar di fasilitas pendidikan sekurangnya $85 \%$ hari efektif belajar.

Dengan melihat data fasilitas pendidikan pada tabel 3 menunjukkan bahwa dukungan fasilitas pendidikan terhadap pelaksanaan PKH di Kota Parepare sangat memadai yang mana semua kecamatan memiliki fasilitas pendidikan mulai dari sekolah dasar, sekolah menengah maupun sekolah menengah atas ataupun kejuruan. Hal tersebut mendukung tercapainya tujuan khusus pelaksanaan program keluarga harapan yaitu meningkatkan taraf pendidikan KPM PKH (Setyawardani, dkk, 2020). Lidiana, dkk. (2014) menyebutkan bahwa dana bantuan dari PKH berpengaruh secara signifikan terhadap tingkat partisipasi pendidikan anak KPM.

Tabel 3. Jumlah Fasilitas Pendidikan per Kecamatan 2019/2020

\begin{tabular}{lccc}
\hline \multicolumn{1}{c}{ Kecamatan } & SD & SMP & SMA \\
\hline Bacukiki & 12 & 7 & 3 \\
Bacukiki Barat & 31 & 9 & 88 \\
Ujung & 24 & 6 & 7 \\
Soreang & 32 & 10 & 12 \\
\hline
\end{tabular}

Sumber: BPS (2020b).

\section{Dukungan Fasilitas Kesehatan}

Masalah kemiskinan berpengaruh terhadap kemampuan masyarakat dalam memenuhi kebutuhan dasarnya diantaranya kecukupan pangan yang rendah yang dipengaruhi oleh daya beli yang rendah, kebutuhan tempat tinggal yang layak, rendahnya pendidikan dan kemampuan akses kesehatan yang rendah. Widianto (2013) menyebutkan bahwa aksesibilitas masyarakat miskin terhadap pelayanan kesehatan masih menemui beberapa kendala di antaranya faktor internal masyarakat itu sendiri yaitu kurangnya partisipasi masyarakat pada kegiatan pelayanan kesehatan yang ada. Faktor eksternal termasuk letak geografis tempat tinggal, administratif yang rumit, maupun terjadinya diskriminasi.

Dalam mewujudkan tujuan PKH dalam meningkatkan status kesehatan dan gizi keluarga penerima manfaat PKH tentu dibutuhkan dukungan fasilitas kesehatan yang memadai khususnya untuk pemeriksaan ibu hamil dan posyandu balita yang merupakan komponen kesehatan bagi penerima manfaat PKH.

Table 4. Jumlah Fasilitas Kesehatan per Kecamatan 2019/2020

\begin{tabular}{lccc}
\hline Kecamatan & $\begin{array}{c}\text { RS/ } \\
\text { Poliklinik/ } \\
\text { RS Bersalin }\end{array}$ & Puskesmas & $\begin{array}{c}\text { Puskesmas } \\
\text { Pembantu }\end{array}$ \\
\hline Bacukiki & - & 1 & 3 \\
Bacukiki & 2 & 1 & 5 \\
Barat & & & \\
Ujung & 2 & 2 & 1 \\
Soreang & 2 & 2 & 4 \\
\hline
\end{tabular}

Sumber: BPS (2020b).

Tabel 4 diatas menunjukkan bahwa fasilitas kesehatan yang ada di kota Parepare sangat memadai dalam mendukung pelaksanaan PKH, setiap kecamatan memiliki puskesmas dan memiliki puskesmas pembantu hal tersebut akan memudahkan masyarakat dalam mengakses pelayanan kesehatan di Kota Parepare.

\section{Pelaksanaan P2K2}

Pertemuan Peningkatan Kapasitas Keluarga (P2K2) bertujuan untuk 
meningkatkan kesadaran dan pengetahuan peserta $\mathrm{PKH}$ tentang pentingnya pendidikan, kesehatan keluarga maupun kualitas hidup keluarga di masa depan. Pelaksanaan P2K2 bagi peserta $\mathrm{PKH}$ bukan hanya sebatas kewajiban akan tetapi ada kesadaran yang diperoleh peserta dalam kegiatan tersebut (Kementerian Sosial, 2018).

Pelaksanaan P2K2 PKH Kota Parepare dilaksanakan setiap bulan pada saat pertemuan kelompok KPM yang biasanya diadakan di gedung pertemuan kelurahan/ kecamatan atau kadang kala dilaksanakan di rumah peserta $\mathrm{PKH}$. Materi P2K2 meliputi pendidikan dan pengasuhan anak, kesehatan dan gizi, perlindungan anak, pengelolaan keuangan keluarga dan kesejahteraan sosial. Materi dibawakan oleh pendamping masingmasing setiap kecamatan dengan jadwal pertemuan telah ditentukan dan disepakati bersama oleh pendamping dan peserta $\mathrm{PKH}$. Pelaksanaan P2K2 di lapangan tentu tidak terlepas dari adanya kendala di lapangan di Abbas, A., Ilham, M., Triani, N., Arizah, A., \& Rayyani, W.O. (2020). The Involvement of Firms in Helping Fight the Pandemic of COVID-19: Evidence from Indonesia (No. us9xm). Center for Open Science.

Aliman, Iman. (2019). Manajemen Pendampingan Program Keluarga Harapan dalam Mewujudkan Wajib Belajar Sembilan Tahun. Jurnal Administrasi Pendidikan, 26 (2), 273282.

Arizah, A., Darwin, K., Ramly, R., \& Abbas, A. (2020). Pandemi COVID-19 dan Gebu CSR pada Perusahaan Adaro Energy. JISIP (Jurnal Ilmu Sosial dan Pendidikan), 4(4).

BPS. (2018). Berita Statistik: Tingkat Kemiskinan Kota Parepare Keadaan Maret 2018. Parepare: Badan Pusat Statistik

BPS. (2020a). Profil Kemiskinan di Indonesia Maret 2020. Berita Resmi Statistik. Profil Kemiskinan di Indonesia Maret 2020 No. 56/07/Th. XXIII, 15 Juli 2020

BPS. (2020b). Parepare Dalam Angka tahun 2020. Badan Pusat Statistik. Parepare: antaranya tempat pelaksanaan $\mathrm{P} 2 \mathrm{~K} 2$ dan kelengkapan sarana dan prasarana yang mendukung pelaksanaan P2K2 ini. Permasalahan tersebut merupakan hal yang umum ditemukan pada pelaksanaan P2K2.

\section{KESIMPULAN}

Program Keluarga Harapan (PKH) di Kota Parepare telah dilaksanakan mulai tahun 2013 hingga saat pandemi. Dalam implementasi PKH di Kota Parepare mendapatkan dukungan positif oleh pemerintah setempat. Pelaksanaan PKH didukung oleh sumber daya manusia yang kompeten di bidangnya, dukungan fasilitas pendidikan dan kesehatan yang memadai serta pelaksanaan P2K2 yang rutin dilaksanakan oleh pendamping untuk meningkatkan kesadaran dan pengetahuan peserta tentang pentingnya pendidikan, kesehatan, serta kesejahteraan sosial.

\section{DAFTAR PUSTAKA}

Direktorat Anggaran Kementerian Keuangan, (2015). Kajian Program keluarga harapan. Kementerian keuangan.

Depi, Z \& Henni, M. (2018). Implementasi Program Keluarga Harapan dalam Meningkatkan Kesejahteraan Keluarga Miskin di Nagari Malampah Kabupaten Pasaman. Journal of Civic Education, 1(4), 384-393.

Kementerian Komunikasi dan Informatika, (2011). Program Penanggulangan Kemiskinan Kabinet Indonesia Bersatu II. Jakarta: Kementerian Komunikasi dan Informatika RI

Kementerian Sosial. (2008). Pedoman Umum Pelaksanaan Program Keluarga Harapan. Jakarta: Kemensos RI

Kemensos. (2020). Pedoman Pelaksanaan Program keluarga Harapan. Jakarta: Kementerian Sosial RI.

Lidiana, Syechalad M.N, \& Nasir M. (2014). Pengaruh dan Efektifitas Bantuan Program Keluarga Harapan (PKH) Terhadap Partisipasi Pendidikan Di Kecamatan Muara Tiga Kabupaten 
Pidie. Jurnal Ilmu Ekonomi, 2(2), 3138.

Purwanto, SA., Sumartono, Makmur, M. (2013). Implementasi Kebijakan Program Keluarga Harapan (PKH) Dalam Memutus Rantai Kemiskinan (Kajian di Kecamatan Mojosari Kabupaten Mojokerto). Wacana, 16, (2), 79-96

Pemerintah Kota Parepare. (2019). Penyusunan RPI2-JM Tahun 2015 2019. Parepare: Pemkot Parepare.

Rusmiyati C. (2018). Dampak Program Keluarga Harapan Bagi Peningkatan Prestasi Anak. Media Informasi Penelitian Kesejahteraan Sosial, 42 (3), 225-234.

Setyawardani, DTR., Paat, CJ., Lesawengen, L. (2020). Dampak Bantuan PKH Terhadap Masyarakat Miskin di Kelurahan Bumi Nyiur Kecamatan Wanea Kota Manado. Jurnal Holistik, 13 (2).

Sugandi, Y.S. (2016). Program

Penanggulangan suatu Kemiskinan Perkotaan: Pengalaman Kota Bandung. 